\title{
Optimization and Economic Analysis of Grid-Photovoltaic Electric Boat Charging Station in Kuala Terengganu
}

\author{
N.A. S. Salleh ${ }^{2}$, W. M. W. Muda ${ }^{1,2}$ and Roslan Umar ${ }^{3}$ \\ ${ }^{1}$ Renewable Energy Research Group \\ ${ }^{2}$ School of Ocean Engineering, University Malaysia Terengganu, Malaysia \\ ${ }^{3}$ East Coast Environment Research Institute, University Sultan Zainal Abidin, Malaysia.
}

\begin{abstract}
This study evaluates the feasibility of developing grid-photovoltaic electric boat charging station in Kuala Terengganu using simulation-based method. The main focus is on reducing the dependency on subsidy spent by the government in fisheries sector and encouraging green technology in commercial sector. All data such as solar radiation, amount of subsidy received by fishermen, and fishing activities were collected for the selected area. Economic analyses of the proposed system are discussed based on payback period and net present cost (NPC). The comparison between the proposed system and the grid-only system is done based on the production and consumption of electricity per year, the NPC and emission of pollutant. The system also generates high income from selling energy to the grid with tariff rates RM $1.49 / \mathrm{kWh}$. It is concluded that the proposed system is feasible to be developed in the selected area with the payback period and the NPC are 8.2 years and RM 759,098, respectively. The results also show that the performance of the proposed system is better than grid-only system in all the interested parameters.
\end{abstract}

\section{Introduction}

The escalating demand of energy and the uses of conventional technology in producing electrical power normally resulted in the pollution that affected everyone. It is because of the emission content which can harm the consumers. Thus, many studies have been proposed regarding renewable energy (RE) sources to replace and reduce the consumption of conventional energy [1-3]. RE is the energy obtained from natural environment like solar, wind, biomass and tidal energy. RE does not only benefit the environment but also for the economy.

Malaysia has a strong potential to exploit RE technologies as the fact that Malaysia is endowed with abundance of natural resources [3]. The potential for solar power generation is very high due to its tropical climate with approximately $4000-5000 \mathrm{Wh} / \mathrm{m} 2$ of daily average solar radiation $[4,5]$. To encourage the use of RE, Malaysia plays their role by lifting it up as the fifth fuel [6]. In Tenth Malaysia Plan [7], Malaysia target to increase the use of RE sources to 985 MW by 2015 , which is $5.5 \%$ to Malaysia's total electricity generation mix. In addition, the Feed-in tariff (FiT) has been introduced to promote the use of RE among consumers [7]. Malaysia also has assigned the Ministry of Energy, Green Technology and Water Malaysia (KeTTHA) that was established in 2009 [8] to focus on the development of green energy.
Since Malaysia is mostly surrounded by seas and ocean, fisheries are one of the contributing sectors in building up the nation's economy. There are almost 90,000 fishermen in Malaysia and $47 \%$ of them involve in offshore fisheries [9]. The fishing activities have been affected by the increase in fuel price. Since most of them are poor [10], the local government has given the fuel subsidies that worth RM 2,133 million in 2007 to almost 33,000 fishermen [9]. The use of electric boat (EB) may solve the abovementioned problem. Using the EB, fishermen do not rely on the fuel, thus the government can reallocate the fuel subsidies to other useful sectors such as agriculture, health and education. In addition, the use of EB may reduce air, marine and noise pollution.

In efforts to promote green technology in fisheries and transportation sectors, EB is one of convincing electric vehicles (EVs) that have potential to reduce pollution and dependency on fuel. Currently, EV charging station systems are connected directly to the grid. It is called Vehicle-to-Grid (V2G) and Grid-toVehicle $(\mathrm{G} 2 \mathrm{~V})$ systems [11]. However, the uncontrolled charging demand from the EV could damage the grid [12]. Thus, the development of RE charging station may reduce the damage.

In this study, an EB charging station with hybrid gridPV system is proposed. The main focus is on the charging station itself. Similar to other countries that have been using EVs [13], only the charging station infrastructure is provided by the government for the EV's user. The cost of EV is assumed to be incurred by the

\footnotetext{
$\overline{2}$ Corresponding author: gsk2357@pps.umt.edu.my
} 
user. Thus, the cost of EB is not considered in this study. It is also well-known that the starting cost of developing RE technology is very expensive [14], so it is important to study the economics analysis in order to know the potential of the proposed system. HOMER software is used to find the optimal size of each component in the system. In addition, the payback period is computed. The income generated from the proposed system by selling excess electricity using FiT rates is then compared with the subsidy spent by government. Furthermore, the performances of PV-grid and grid only system are also compared in terms of net present cost (NPC), electricity production and consumption per year, and emission of pollutant. The proposed system is targeted to be used for offshore fishermen only.

\section{Charging Station System Configuration}

The proposed system configuration is as shown in Figure 1. The electricity generated by PV is used to charge the EB battery which is load in this system. The excess electricity generated by PV is stored in batteries. Any other excess electricity is sold to the grid by following FiT scheme. Grid also is used as backup where it supplies electricity to the load when there is insufficient energy from PV and batteries. A converter is used in this configuration to convert $\mathrm{AC}$ to $\mathrm{DC}$ and vice versa as the EB battery used in this system is a DC load.

A selected area for this study is Kuala Terengganu Utara (KTU) with latitude and longitude are 5.31 and 103.12, respectively [5]. HOMER software requires some input parameters to calculate the optimization results for a specific configuration of system. The input parameters are daily solar radiation $(\mathrm{kWh} / \mathrm{m} 2 / \mathrm{d})$ and load profile $(\mathrm{kW})$. In addition, the specification for each component used such as PV, batteries, converter and grid are also needed.

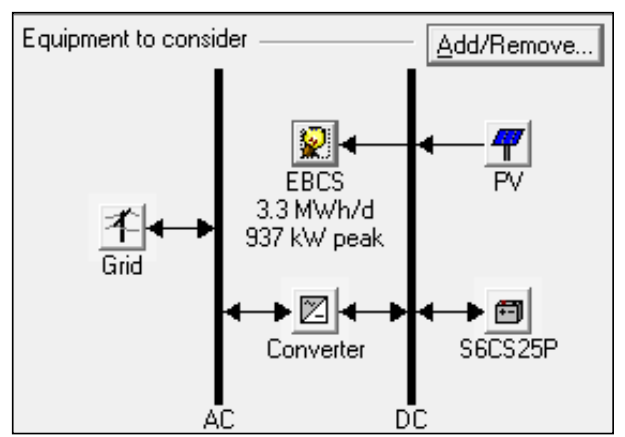

Figure 1. System configuration of grid-PV system in HOMER

\subsection{Load Profile/ Load Demand}

To determine the load profile, 16 out of 242 fishermen in KTU were selected for interview sessions to know about their fisheries activities. Another interview session with Lembaga Kemajuan Ikan Malaysia (LKIM) Chendering [15] was conducted to validate the data obtained from interview with fishermen. Besides, the information on the total amount of fuel subsidy and government incentive was also acquired from them. All the collected data are summarized in Table 1.

Table 1. Summarization of data obtained from interview sessions

\begin{tabular}{|l|l|}
\hline \multicolumn{1}{|c|}{ Subject } & \multicolumn{1}{c|}{ Data } \\
\hline No. of fishermen & 242 \\
\hline Fuel subsidy (Petrol) & RM 1.65/litre \\
\hline $\begin{array}{l}\text { Engine power (horsepower, } \\
\text { hp) }\end{array}$ & $15,30,40,60$ \\
\hline $\begin{array}{l}\text { Operating hours } \\
\text { for offshore fishermen only) }\end{array}$ & $\begin{array}{l}\text { Approximately } 6.30 \text { a.m. - } \\
2.00 \text { p.m. } \\
\text { (except for Nov-Feb, no } \\
\text { fishing activities) }\end{array}$ \\
\hline Distance from land & $\approx 20$ miles =32 km \\
\hline Duration taken to fishing area & $\approx 1$ hour \\
\hline $\begin{array}{l}\text { Total subsidy for KTU in } \\
2014 \text { (RM/yr) }\end{array}$ & RM 1,228,325.70 \\
\hline
\end{tabular}

From Table 1, engine power with $60 \mathrm{hp}$ is considered in determining the load profile of the proposed system. To replace $60 \mathrm{hp}$ engine, the $\mathrm{EB}$ needs $45 \mathrm{~kW}$ electric motor. Inspired by [16], a 20kWh Li-ion battery is chosen in this study to be used to supply electricity to electric motor. Since 1 unit EB battery needs approximately one hour to fully charge, and the charging station is used after operating hours which is 2 p.m. till 12 p.m. only, the total EB battery can be charged in one unit charging station is 10 units/day. In order to provide the facilities to all fishermen in KTU, 25 unit charging stations are needed. Assuming that all 25 units are used to charge $20 \mathrm{kWh}$ battery at one time, so the maximum amount of load in a day for this system is $500 \mathrm{~kW}$ for 10 hours.

Figure 2 shows the load profile of the case study area. There is no charging activity during the day until 2 p.m. because the fishermen are out for their fishing activities. The load profile starts to be at peak after 2 p.m. as the fishermen are home to recharge their battery boat at the charging station. During Northeast Monsoon from November to February, the load profile becomes null because the fishermen not be able to go out for fishing. Thus, no charging activities occur for four months. In order to avoid confusion between the EB battery and batteries used to store energy in the system, the EB battery is referred to load for the rest of this paper.

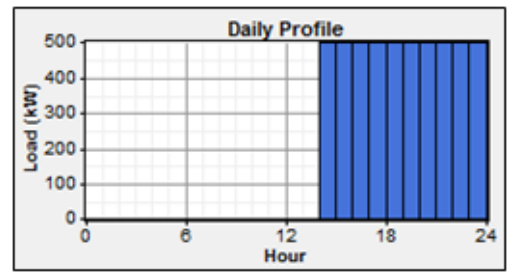

Figure 2. Load profile of March - October

\subsection{Solar Resources}

Solar radiation data was collected from UNISZA weather station [17] and the solar radiation for selected area is shown in Figure 3. 


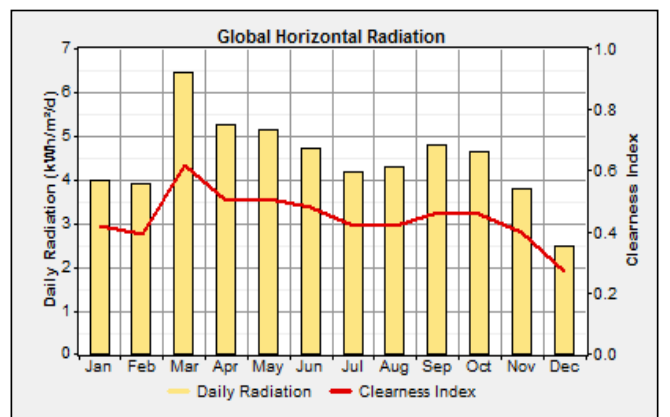

Figure 3. The annual solar radiation and the clearness index of Kuala Terengganu, Terengganu.

According to Figure 3, the clearness index of solar radiation data is calculated by HOMER with the following daily radiation data entered. The range of solar radiation is from $2.493 \mathrm{kWh} / \mathrm{m} 2 /$ day to 6.447 $\mathrm{kWh} / \mathrm{m} 2 /$ day and the average of solar radiation is 4.472 $\mathrm{kWh} / \mathrm{m} 2 /$ day. From the graph plotted, it is noticeable that solar irradiance from March to October is high meanwhile; it is low from November to February due to the Northeast Monsoon season.

\subsection{Grid Utility and Feed-in-Tariff}

There are two types of grid utility system in Malaysia which are, a single phase system with $240 \mathrm{~V} / 50 \mathrm{~Hz}$ AC and 3-phase system with $415 \mathrm{~V} / 50 \mathrm{~Hz} \mathrm{AC}$ [18]. In case if there is deficit energy from the renewable energy source system, grid acts as backup supplier of energy. Tenaga Nasional Berhad (TNB) [19] is responsible in managing grid utility in Malaysia. Meanwhile, Sustainable Energy Development Authority (SEDA) [20] of Malaysia is a statutory body to administer and manage the implementation of the FiT mechanism which is mandated under the Renewable Energy Act 2011 (Act 725).

This project uses the Tariff C1; Medium Voltage General Commercial Tariff [19] with the commercial rate and maximum demand RM $0.365 / \mathrm{kWh}$ and RM $30.3 / \mathrm{kW} /$ month, respectively. The FiT rate is fixed at RM $1.49 / \mathrm{kWh}[21]$.

\subsection{Photovoltaic (PV) system}

The PV specification for this system is obtained from [21, 22] which consider the $\mathrm{PV}$ price at $\mathrm{RM} 2.55 / \mathrm{W}$. Considering mounting and installation cost of $3 \mathrm{~kW}$ PV is RM 20,000, the initial cost of PV is RM 27,650. The replacement cost is assumed to be the same. Since the peak of load demand is $937 \mathrm{~kW}$, and the load requires 3.3 $\mathrm{MWh} /$ day, the sizing range of $\mathrm{PV}$ is considered from $0-$ $3400 \mathrm{~kW}$, where $0 \mathrm{~kW}$ is used to see the possibility of configuration without PV panel. As Terengganu itself has a monsoon season with heavy rainfall, the cleaning cost can be negligible because it does not require regular cleaning process. The derating factor of this PV module is $80 \%$ with a lifetime of 25 years [21].

\subsection{Inverter}

4 units of $250 \mathrm{~kW}$ Sunny Central $250 \mathrm{U}$ inverter are used in this system to satisfy the total output of $1 \mathrm{MW}$ load profile. The configuration of the inverter are based on $[23,24]$ which cost RM 448,920 with operating and maintenance approximately $0.3 \%$ from its cost. The inverter has a 20 years lifetime with output power factor 0.97 .

\subsection{Battery storage}

The model Surrete 6CS25P [25] battery are chosen as storage element in this system. The arrangement of battery is important to ensure the energy capacity produced is high to support the electricity gained from the PV and grid. Thus, the sizing range of the battery is considered from 0 to 10 units as the storage of energy.

\section{System Analysis}

A few analyses can be carried out in HOMER from a grid-PV charging station system. In term of economics feasibility, NPC and payback period can be analysed. Moreover, this study compares between the cost needed to spend on 25 years of the charging station and the subsidy spent by the government on fuel for the fishermen.

\subsection{Net present cost (NPC)}

The NPC considers the cost throughout the system lifetime including the initial costs, replacement costs, operating and maintenance costs and grid rate costs. Generally, total NPC is calculated using the following equation (1) to equation (3) of [21];

$$
\begin{aligned}
& N P C=\frac{C_{a n n, t o t}}{\operatorname{CRF}(i, N)} \\
& C R F(i, N)=\frac{i(1+i)^{N}}{(1+i)^{N}-1} \\
& i=\frac{i^{\prime}-f}{1+f}
\end{aligned}
$$

From the equation presented above, all cost of capital, replacement, annual operating and maintenance are included in the total annualized cost, $\mathrm{C}_{\mathrm{ann}}$, tot. $\mathrm{N}$ is the number of years. Meanwhile, CRF is the capital recovery factor which the annual interest rate, $i$, can be calculated using equation (3) where $i$ ' is the nominal interest rate and $f$ is the annual inflation rate.

Until March 2015, Department of Statistics Malaysia reported the inflation rate in Malaysia is $0.90 \%$ and the nominal interest rate is $3.25 \%[26,27]$. As a result, the annual real interest rate is $2.33 \%$. 


\subsection{Payback period}

The Payback Period is the length of time it takes for a project to generate enough cash flow to pay back the initial investment. Payback period is the ratio of the extra first cost, $\Delta \mathrm{P}$ to the annual savings, $S$ as written in equation (4) [28]:

$$
\text { Payback period }=\frac{\text { Extra first cost }, \Delta P(\$)}{\text { Annual saving }, S(\$ / y r)}
$$

\section{Results and analysis}

The outcome shows the grid-PV system and the grid-only system based on 25 years project lifetime with annual interest rate of $2.33 \%$. The simulation results were generated by HOMER with configuration of $3000 \mathrm{~kW}$ grid-PV modules and $1000 \mathrm{~kW}$ converter, representing the most feasible system. The optimization results are shown in Figure 4.

\begin{tabular}{|c|c|c|c|c|c|c|c|c|c|}
\hline \multicolumn{10}{|c|}{\begin{tabular}{|l|} 
Senstivity Results Optimization Results \\
\end{tabular}} \\
\hline \multicolumn{10}{|c|}{ Double click on a system below for simulation results. } \\
\hline 1甲甲国图 $\begin{array}{c}P V \\
(\mathrm{~kW})\end{array}$ & S6CS25P & $\begin{array}{l}\text { Conv. } \\
(\mathrm{kW})\end{array}$ & $\begin{array}{l}\text { Gind } \\
(\mathrm{kW})\end{array}$ & $\begin{array}{l}\text { Intitial } \\
\text { Capital }\end{array}$ & $\begin{array}{l}\text { Operating } \\
\text { Cost }(\$ / y r)\end{array}$ & $\begin{array}{l}\text { Total } \\
\text { NPC }\end{array}$ & 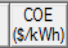 & $\begin{array}{l}\text { Ren. } \\
\text { Frac. }\end{array}$ & \begin{tabular}{|l} 
Batt. Lf. \\
(vi)
\end{tabular} \\
\hline 1甲娄 3000 & & 1000 & 1000 & $\$ 29,445,680$ & $-1,526,876$ & $\$ 759,098$ & 0.033 & 0.82 & \\
\hline 3000 & 1 & 1000 & 1000 & $\$ 29,449,484$ & $-1,527,006$ & $\$ 760,449$ & 0.033 & 0.82 & 12.0 \\
\hline 圆 & & 1000 & 5000 & $\$ 1,795,680$ & 790,610 & $\$ 16.649 .483$ & 0.726 & 0.00 & \\
\hline 10 & 1 & 1000 & 5000 & $\$ 1,799,484$ & 790,806 & $\$ 16,656,957$ & 0.726 & 0.00 & 12.0 \\
\hline
\end{tabular}

Figure 4. Optimization results of grid-PV system

Grid-PV system is the most optimal system with total NPC is the lowest at RM 759,098 with cost of electricity (COE) at RM $0.033 / \mathrm{kWh}$. The negative value of operating cost is obtained because of the power generated from the system is sold to the grid is much higher than the power purchased from the grid to the load. This can be seen clearly as shown in the cash flow summary of grid-PV system in Figure 5. Grid-PV system with battery has a higher NPC than grid-PV system due to the cost of battery. Note that, the system only require 1 unit battery although the sizing range is set up to 10 units because selling extra electricity to the grid is more profitable than store it in the battery. For grid- only system, it might not invest much in capital cost but shows the highest total NPC at RM 16,649,483, and COE at RM 0.726/kWh. Note also that, the COE for grid only system is higher than the tariff given by TNB because the system requires converter that contributes to the increasing of COE.

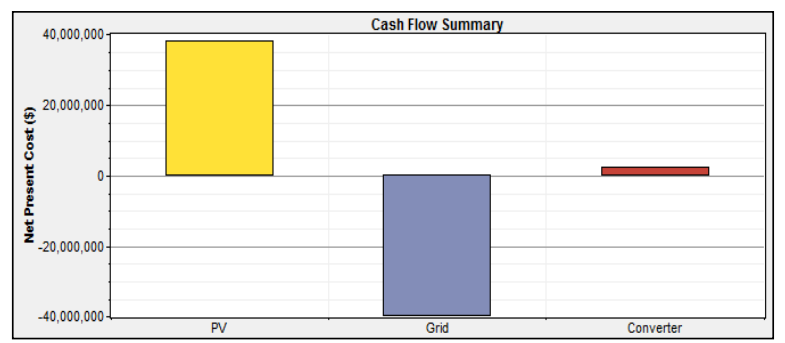

Figure 5. Optimization results of grid-PV system

The production and consumption of electricity for grid-PV and grid-only systems are shown in the following Figure 6 and Figure 7, respectively. For gridPV system, the figures show that PV module produced
$3,914,504 \mathrm{kWh} /$ year of electricity with $82 \%$ from electricity produced by the system and another $18 \%$ of electricity was purchased from the grid with 849,924 $\mathrm{kWh} /$ year. Loads used up to $1,220,886 \mathrm{kWh} /$ year of electricity with approximately $34 \%$ of electricity production while $66 \%$ of excess electricity was sold to the grid at 2,419,648 $\mathrm{kWh} /$ year with rates RM 1.49/kWh. Electricity produced by the grid-only system is $1,436,381$ $\mathrm{kWh} /$ year and electricity consumption by the load is $1,220,923 \mathrm{kWh} /$ year with $215,458 \mathrm{kWh} /$ year electricity losses. No energy was sold to the grid because the amount of energy purchased from the grid was used up by the loads.

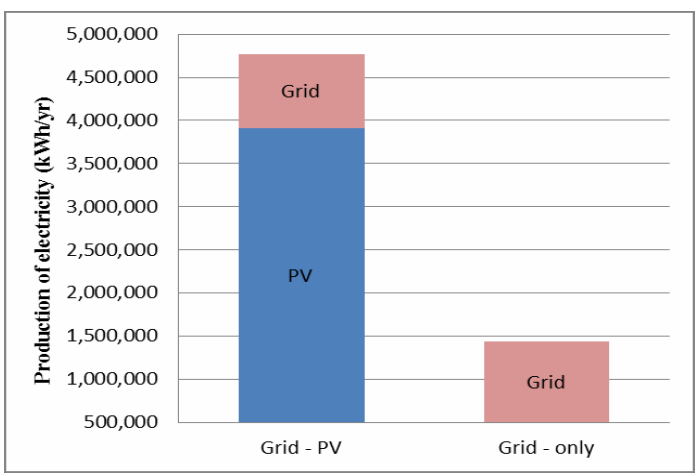

Figure 6. Production of electricity

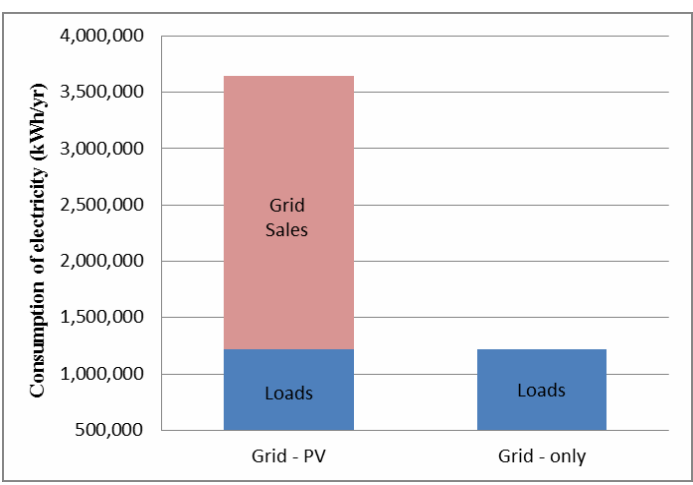

Figure 7. Consumption of electricity

This system has no exception in generating pollutants. In fact, greenhouse gases are emitted due to the energy from grid as the energy is generated with fossil fuel [29]. Because of this system still needs to purchase energy from the grid as supporting energy; this contributes to the emission of greenhouse gasses. However, with grid-PV system, there was a reduction of emission compared to the grid-only system to $373,034 \mathrm{~kg} /$ year that is $40 \%$ in reduction of emission. The results are shown in Table 2.

Table 2. The pollutant emission of systems.

\begin{tabular}{ccc}
\hline & \multicolumn{2}{c}{ Emissions of systems (kg/yr.) } \\
\cline { 2 - 3 } Pollutant & Grid-only & Grid-PV \\
\hline Carbon dioxide & 907,793 & 537,152 \\
Carbon monoxide & 0 & 0 \\
Unburned hydrocarbon & 0 & 0 \\
Particulate matter & 0 & 0 \\
Sulphur dioxide & 3,936 & 2,329 \\
Nitrogen oxide & 1,925 & 1,139 \\
\hline Total emission & $\mathbf{9 1 3 , 6 5 4}$ & $\mathbf{5 4 0 , 6 2 0}$ \\
\hline
\end{tabular}




\subsection{Grid-PV system}

Figure 8 shows the production of electricity from PV in yellow colour. The electricity from the grid is still need to be purchased to supply electricity to the load especially at night. However, during Northeast Monsoon, the electricity produced by PV are fully sold to the grid because no fishing activities during this season. Thus, the amount of power sold to the grid is higher than the grid purchased for the loads. The consumption of electricity by the loads is $1,220,886 \mathrm{kWh} /$ year which was approximately $34 \%$ from the production of electricity. Therefore, the $66 \%$ of excess electricity were sold to the grid at 2,419,648 $\mathrm{kWh} /$ year with rates RM 1.49/kWh.

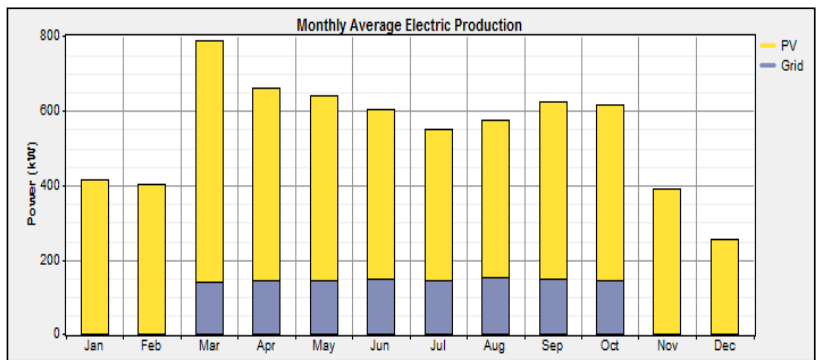

Figure 8. Monthly average electricity production of grid-PV system

\subsection{Payback period}

Payback period of the system can be determined from equation (4). With rates RM 1.49/kWh and cost of energy sold to the grid-PV system, the annual saving of the system is RM 3,605,275.52/year. Thus, the payback period is 8.2 years

\subsection{Malaysia Subsidy Scheme}

Based on [15], the amount of fuel subsidy received by the fishermen at Kuala Terengganu Utara area in 2014 was RM 1,228,325.70. Total income from selling the electricity of the proposed system is higher than the amount of subsidy spent by the government which was RM 3,605,275.52/year. Thus, this initiative is one of ways to reduce the government spending on fuel subsidy in fisheries sector and to raise fund in other sector such as education and medical sector.

\section{Conclusions}

In order to reduce fuel consumption and subsidies from the government, the idea of grid- PV charging stations system is produced. Besides being able to reduce the cost of subsidies, it can also reduce fuel consumption and thus reduce pollution by using cleaner energy from renewable energy sources, namely solar energy. It is feasible to develop EB charging station in Kuala Terengganu. Moreover, grid-PV system is much better than grid-only system in term of cost and emission as mentioned before. Even though the installation cost of PV is expensive, but it only takes 8.2 years to gain the payback period of the system. In addition, the revenue of the system is higher than the subsidy spending by the government on fuel. All in all, this system is beneficial in aspects of cost, emission and good returns in the future.

\section{Acknowledgement}

The financial support of this work by the Fundamental Research Grant Scheme (FRGS) and Universiti Malaysia Terengganu is gratefully acknowledged.

\section{References}

1. S. Mekhilef, A. Safari, W. E. S. Mustaffa, R. Saidur, R. Omar, M. A. A. Younis, Solar energy in Malaysia: Current state and prospects. Renewable and Sustainable Energy Reviews 16, 386-396 (2012)

2. B. Parida, S. Iniyan, R. Goic, A review of solar photovoltaic technologies. Renewable and Sustainable Energy Reviews 15, 1625-1636 (2011)

3. R. Ali, I. Daut, S. Taib, A review on existing and future energy sources for electrical power generation in Malaysia. Renewable and Sustainable Energy Reviews 16, 4047-4055 (2012)

4. S. Mekhilef, M. Barimani, A. Safari, Z. Salam, Malaysia's renewable energy policies and programs with green aspects. Renewable and Sustainable Energy Reviews 40, 497-504 (2014)

5. W. M. W. Muda, C. A. Fong, Simulation-based method to evaluate pv-wind hybrid renewable energy system in Terengganu. Energy and Sustainability $V$ 186, 91-102 (2015)

6. Pusat Tenaga Malaysia (PTM), Energy Sector Embracing Climate Change. Paper presented at National Conference on Climate Change Preparedness Towards Policy Changes, (2007)

7. Tenth Malaysia plan 2011-2015 (2010)

8. Kementerian Tenaga Teknologi Hijau dan Air, (KeTTHA). Available: http://www.kettha.gov.my/portal/index.php [Accessed 16th May 2015]

9. A. M. Yusof, Z. Mahbar, in Proceeding of PERKEM III, 268-279 (2008)

10. N. H. Sa'at, Social mobility among the coastal community: A case study in kuala terengganu. Kajian Malaysia 29, 95-123 (2011)

11. G. Fabbri, G. Tarquini, L. Pasquali, L. Anniballi, S. Odoardi, S. Teodori, E. Santini, in Industrial Electronics (ISIE), 2014 IEEE 23rd International Symposium, 1677-1682 (2014)

12. Vítor Monteiro, J. C. Ferreira, J. L. Afonso, paper presented at the $1^{\text {st }}$ International Conference on Smart Grids and Battery IT Systems, (2012)

13. L. Liu, F. Kong, X. Liu, Y. Peng, Q. Wang, A review on electric vehicles interacting with renewable energy in smart grid. Renewable and Sustainable Energy Reviews 51, 648-661 (2015)

14. T. Khatib, K. Sopian, H. A. Kazem, Actual performance and characteristic of a grid connected photovoltaic power system in the tropics: A short term evaluation. Energy Conversion and Management 71, 115-119 (2013) 
15. Lembaga Kemajuan Ikan Malaysia, (LKIM). Available: http://www.lkim.gov.my/ [Accessed 16th May 2015]

16. S. Minami, K. Koizumi, T. Hanada, N. Matsuda, K. Ishizu, J. Nishi, T. Fujiwara, in Electric Vehicle Symposium and Exhibition (EVS27), 2013 World, 14 (2013)

17. East Coast Environmental Research Institute (ESERI), Universiti Sultan Zainal Abidin (UniSZA). Available: http://www.unisza.edu.my/eseri/ [Accessed 10 February 2015]

18. M. A. A. F. Yousif, E. Alfegi, N. Asim And K. Sopian, paper presented at the 7th International Conference on Renewable Energy Sources (RES '13), Kuala Lumpur, Malaysia, (2013)

19. Tenaga Nasional Berhad (TNB). Available: https://www.tnb.com.my/ [Accessed 30 March 2015]

20. Sustainable Energy Development Authority (SEDA). Available: http://www.seda.gov.my/\#tab-A [Accessed 30 March 2015]

21. R. N. S. R. Mukhtaruddin, H. A. Rahman, M. Y. Hassan, in Clean Electrical Power (ICCEP), 2013 International Conference, 577-583 (2013)

22. Sharp Electronics Corporation. Sharp-ND204QCJ datasheet. Available: www.sharpusa.com/solar [Accessed 21 ${ }^{\text {st }}$ May 2015]

23. W. Y. Teoh, S. Y. Khu, C. W. Tan, I. H. Hii, K. W. Cheu, Technoeconomic and carbon emission analysis for a grid-connected photovoltaic system in malacca. ISRN Renewable Energy 2012, 8 (2012)

24. SMA America Inc. Sunny Sentral 250U/500U Datasheet. Available: https://www.civicsolar.com [Accessed 21 ${ }^{\text {st }}$ May 2015]

25. M. S. Ngan, C. W. Tan, Assessment of economic viability for $\mathrm{PV} /$ wind/diesel hybrid energy system in southern Peninsular Malaysia. Renewable and Sustainable Energy Reviews 16, 634-647 (2012)

26. Trading Economics. Available: http://www.tradingeconomics.com/ [Accessed 6th May 2015]

27. Malaysia Energy Information Hub (MEIH). Available: http://meih.st.gov.my/statistics [Accessed 6th May 2015]

28. M. M. Gilbert, in Renewable and efficient electric power systems. (John Wiley and Sons, New York, 2004), chap. Chapter 5: Economics of Distributed Resources, 240-254 (2014)

29. B. Norton, P. C. Eames, S. N. G. Lo, Full-energychain analysis of greenhouse gas emissions for solar thermal electric power generation systems. Renewable Energy 15, 131-136 (1998) 